\title{
Analyzing Student Learning in Sustainability: An International Exchange Case Study
}

\author{
Linda S. Jones \\ SUNY/Empire State College \\ Rhianna C. Rogers \\ SUNY/Empire State College \\ Mark Abendroth \\ SUNY/Empire State College
}

\begin{abstract}
The use of technologies to bridge learning divides is an important topic in $21^{\text {st }}$ century higher education. As an innovation to address this divide, the SUNY Empire State College - International Education - Virtual Residencies (IE-VRS) were created. The IE-VRs are virtual, international exchanges that connect undergraduate, graduate, and international education courses via a three-week collaborative, crossdisciplinary online module. We built a thematic IE-VR titled "Learning for a Sustainable Future," which focused on the UN Sustainable Development Goals and sustainability in socio-cultural-environmental contexts. Our analysis of student participation in the IE-VR indicates it is an effective model for transformative learning.
\end{abstract}

Keywords: education, international exchange, sustainable development, sustainability, transformative learning, virtual learning

\section{INTRODUCTION}

Before COVID, most educational institutions had limited experience with effective online learning strategies. Whether through the limitation of online training, reliance on particular schools of thought, or a general failure to incorporate the latest trends, these outdated models limited the learners' ability to meaningfully engage online. As we have seen in the COVID-19 era, the world is changing, and we can no longer accept "the same old same old." The innovative International Education - Virtual Residencies (IEVRs) format challenges this traditional notion of learning through its adoption of a transformative design framework (i.e., utilizing asynchronous/synchronous online assignments that employ reflexivity, applied learning, and cultural competencies to create spaces for student engagement and exchange). As we have learned, today's students are contending with complex socio-cultural issues, rapidly changing technologies, new modes of learning as well as global social-cultural unrest. The need for learners to grapple with and address sustainability challenges, like global warming, food deserts, healthcare disparities, poverty, and social unrest is no longer an option, but critical parts of global citizenry. These challenges require new skills 
and educational attitudes which we, as educators, must address in our curriculum to stay relevant. The future of this world depends on the sustainable practices we implement today and how we instill them in the learners of the future. To support new sustainable education practices, we need to educate students about their ability to influence sustainability processes in creative ways. With this approach in mind, this paper analyzes student data from the Fall 2020 SUNY Empire State College IE-VR titled "Learning for a Sustainable Future," a virtual, international exchange that connected ten undergraduate, graduate, and international education courses via a three-week collaborative, cross-disciplinary online module (Abendroth, Rogers, \& Jones, 2020). Our goal in this paper is to illustrate that the IE-VR framework encourages students to co-create an engaging online learning environment where they develop crossdisciplinary research and civic responsibility. Overall, our data and findings are meant to provide educators with a tested online learning framework in hopes of encouraging others to develop spaces for transformative learning and collective action.

\section{International Education - Virtual Residency Model (2017 - Present)}

Under the coordination of Dr. Rhianna C. Rogers, SUNY Empire State College (SUNY Empire) adopted the innovative platform, International Education - Virtual Residencies (IE- VRs) as a space to create engaging online thematic forums for students to explore complex issues (Mercer, Pisutova, \& Rogers, 2018). Since their creation in 2017, IE-VRs have existed as a partnership between the college's Center for International Education and Rogers' Buffalo Project (Rogers, 2020a). To date, Rogers has facilitated and/or co-facilitated nine IE-VRs, ranging in themes and disciplinary foci. The goals of IE-VRs are to utilize timely topics to create spaces for transformative learning experiences to prepare students to meet the complex environmental, social, and cultural challenges they are facing in their everyday lives.

\section{Fall 2020 Learning for a Sustainable Future International Education - Virtual Residency}

As part of a 2020-2021 SUNY Empire Institute on Mentoring, Teaching, and Learning (IMTL) research project, we created the "Learning for a Sustainable Future" themed IE-VR. The theoretical scope and content of this IE-VR were intentionally broad and drew from the UN Sustainable Development Goals (SDGs) as well as the interdisciplinary concepts of transformative learning, intercultural competencies, environmental justice, and sustainability in socio-cultural-environmental contexts. Given the international nature of this IE-VR, specific emphasis was placed on the UN goals Climate Action (SDG \#13) and Reduced Inequality (SDG \#10); however, students could research other SDGs of interest (United Nations, 2020a). In the Fall of 2020, ten undergraduate, graduate, and International Education courses were brought together for three weeks to engage in this IE-VR experience (See Table 1).

TABLE 1

\section{LIST OF COURSES FOR THE FALL 2020 IE-VR}

\begin{tabular}{|l|l|l|l|}
\hline Course & Program & Level & Instructor \\
\hline Anthropology of Art & $\begin{array}{l}\text { International Education - } \\
\text { Lebanon - Social Science }\end{array}$ & Advanced/Undergraduate & $\begin{array}{l}\text { Dr. Rhianna } \\
\text { Rogers }\end{array}$ \\
\hline \multirow{3}{*}{ Digital Storytelling } & Empire Online Arts & Advanced/Undergraduate & Dr. Tom Mackey \\
\cline { 2 - 4 } & $\begin{array}{l}\text { International Education - } \\
\text { Prague }\end{array}$ & Advanced/Undergraduate & Dr. Sheila Aird \\
\hline Ecology & Natural Science & Advanced/Undergraduate & Dr. Kevin Woo \\
\hline $\begin{array}{l}\text { Health Disparities \& } \\
\text { Family }\end{array}$ & $\begin{array}{l}\text { Community Human } \\
\text { Services }\end{array}$ & Advanced/Undergraduate & $\begin{array}{l}\text { Dr. Anamaria } \\
\text { Ross }\end{array}$ \\
\hline $\begin{array}{l}\text { Infections and } \\
\text { Epidemics: Biocultural } \\
\text { Perspectives }\end{array}$ & $\begin{array}{l}\text { Community Human } \\
\text { Services }\end{array}$ & Advanced/Undergraduate & $\begin{array}{l}\text { Dr. Anamaria } \\
\text { Ross }\end{array}$ \\
\hline
\end{tabular}




\begin{tabular}{|l|l|l|l|}
\hline $\begin{array}{l}\text { Principles of Community } \\
\text { \& Economic } \\
\text { Development }\end{array}$ & Policy Studies & Graduate & $\begin{array}{l}\text { Dr. Joseph } \\
\text { Angiello }\end{array}$ \\
\hline $\begin{array}{l}\text { Sex \& Gender in Global } \\
\text { Perspective }\end{array}$ & $\begin{array}{l}\text { Empire Online - Social } \\
\text { Science }\end{array}$ & Advanced/Undergraduate & $\begin{array}{l}\text { Dr. Rhianna } \\
\text { Rogers }\end{array}$ \\
\hline $\begin{array}{l}\text { Special Topics: Digital } \\
\text { Transformation for } \\
\text { Digital \& Societal } \\
\text { Advancements }\end{array}$ & $\begin{array}{l}\text { Computer Science \& } \\
\text { Technology }\end{array}$ & Advanced/Undergraduate & Dr. Ivan Ivanov \\
\hline $\begin{array}{l}\text { Special Topics: The } \\
\text { Political Economy of } \\
\text { Waste }\end{array}$ & $\begin{array}{l}\text { International Education - } \\
\text { Prague - Business }\end{array}$ & Advanced/Undergraduate & Prof. Tanweer Ali \\
\hline $\begin{array}{l}\text { Virtual Addictions in the } \\
\text { 21st Century }\end{array}$ & $\begin{array}{l}\text { Community Human } \\
\text { Services }\end{array}$ & Advanced/Undergraduate & $\begin{array}{l}\text { Dr. Rebecca } \\
\text { Elias-Aras }\end{array}$ \\
\hline
\end{tabular}

As part of the three-week IE-VR, participants spent two weeks critically analyzing global sustainability practices through the lens of the SDGs. In the third week, participants analyzed sustainability case studies and reflected on their own and international classmates' responses to apply course content to their actionbased microstudies. A highlight of this exchange was a synchronous cross-disciplinary virtual panel of scholars, practitioners, and sustainability activists who discussed the topic of sustainability from their academic and professional perspectives (Rogers, 2020c).

Before the start of the term, faculty were provided with training opportunities around online learning strategies, intercultural competencies, and SDGs. All faculty were encouraged to incorporate IE-VR themes into their affiliated course content (See Table 2). Once the experience began, faculty and students were encouraged to explore the interdependent nature of environmental, social, and cultural systems highlighted in the learning materials.

TABLE 2

FACILITATING DEEP LEARNING DURING THE IE-VR: MESSAGE TO INSTRUCTORS

1. We will be using Moodle to host our courses in this Residency: If you are unfamiliar with Moodle, that is no problem, I will be here to help you think of ways to engage students in your course and/or in creative ways at a distance.

- To get you started, this website offers some great ideas for you to think about during your Moodle course design process: https://www.uwb.edu/globalinitiatives/academic/coil-initiative/coil-resources

2. Review other collaborations online to get ideas: I would suggest SUNY TOEP, SUNY COIL, and Open SUNY websites and their associated resources for ideas and brainstorming.

- You can also take a look at this collaborative module I co-created with a colleague at SUNY Old Westbury, Dr. Andrew Hashey, for more inspiration as well: https://sites.google.com/site/coillearninginthedigitalage/

3. Review your syllabus/learning contract and see how you can build in the IE-VR in meaningful ways: Based on previous data, the IE-VR experience is enhanced when faculty require all or part of the IE-VR 3 week exchange in their courses.

4. Familiarize yourself with Zoom: Just remember, if you have questions about Zoom, feel free to reach out to me. We have professional accounts at the college which we will use for this residency, but it would not be a bad idea to create a free account and practice with it. https://zoom.us/ 
5. Consider building in the residency themes into your course/collaborative module. As was indicated in the initial call, we are looking for:

- Community, Political Systems, and Responsible Citizenship. An example is "Promoting global citizenry in the 21st-century globalized world."

- Global Issues and Solutions to Issues of Biodiversity; Global Weather/Climate/Climate Change; Ecosystems; Energy and Uses; and, Water and Food Sustainability.

- Thoughts about themes that speak to your own disciplinary or cross-disciplinary interpretation of building community. Examples may include: Developing crosscultural teams in virtual spaces and learning environments; developing local community outreach opportunities; utilizing community partnerships; creating dialogues across cultural lines and communities; and, other innovative approaches to community development.

- NOTE: The "Learning for a Sustainable Future" IE-VR theme is meant to be inclusive of any populations across the globe, including mainstream, marginalized communities, and countercultures. (R. Rogers, personal communication, May 19, 2020).

To encourage discussion of the 17 global SDGs, as outlined by the United Nations, we developed curricula that positioned creative thinking, effective decision-making, and reflection as guides for transformative learning attainment (United Nations, 2020b). Participants were asked to consider ways that issues/challenges in one system ripple through the other systems, resulting in unsustainable conditions such as environmental degradation, poverty, and social unrest. They were also encouraged to consider the ways that solutions could be informed by scientific data and socio-cultural perspectives to achieve SDGs by 2030. Throughout the IE-VR, students were invited to reflect on their "sustainable worldview" and propose tangible solutions to systemic environmental, social, and cultural issues. Our data, provided below, indicates that the IE-VR model worked particularly well because the framework itself mirrors the complexities of sustainable development and the SDGs. For example, the IE-VR learning community was intentionally made up of stakeholders with different levels of education, (i.e., faculty and graduate, undergraduate, and international students). This population was comprised of different cultural backgrounds (e.g., race/ethnicity, language, socioeconomic status) and different fields of expertise (See Table 1). As a result, there is an inherent diversity among the individuals participating in discussions, which encouraged divergent thinking on the development and evaluation of sustainable solutions to unsustainable situations. As a byproduct of this experience, students not only learned about sustainability in a global context but also gained intercultural competencies via interacting with others who may or may not share their "sustainable worldview."

\section{Adopting an Effective Online Learning Model}

The systematic development of deep learning (or the critical way to engage learners in applied learning skills and activities) is one such way to teach learners about the importance of sustainable practices. In IEVRs, educational content is continuously evolving to reach different populations, including those challenged by their socio-economic status and access to technology (Philip, 2015). Inevitably, these new educational delivery methods are changing the way students learn and want to be taught (Rogers, 2020b). The need for innovative teaching and learning approaches is especially apparent when institutions take part in international student collaborations where student experience can be remarkably different across various cultural groups. The intentional use of multiple technologies in the IE-VR format (e.g., Zoom, WhatsApp, Moodlerooms, and Google platforms) allows for multiple entry points for students who may not have the same access (Mercer, Pistova, \& Rogers, 2018). In many ways, IE-VRs serve as a clear example of inclusive, sustainable education practices; one that can and should be used more broadly. By proactively thinking about diversity, this format encourages the development of both safe spaces (where learners feel 
comfortable) as well as brave spaces (where learners are confident they can share ideas without judgment). These spaces inevitably increase dialogue between diverse groups. For example, the science community is in consensus that climate change is caused largely by human activity and that irreversible catastrophic damage will be the result if humans do not act to reverse the rise of greenhouse gases (Costello et al., 2009). Conversely, some religious communities argue that climate change does not exist and/or that its impacts are not as adverse as stated by science (Haluza-DeLay, 2014). Interestingly, though these perspectives were reflected in the IE-VR, no conflicts arose between students. These interactions indicate to us that the environment we developed encouraged students to engage in dialogue rather than argument.

In addition, 8 out of the 10 participating IE-VR instructors reported that online classroom engagement increased during their 3-week experience, specifically citing that the interactive and collaborative nature of the IE-VR experience (the inclusion of safe and brave spaces) gave students the confidence to share their beliefs about SDGs. Instructors specifically noted that the reflexive elements of the IE-VR model (e.g., Keynote panels, reflective discussion forums, building-block assignments, and a culminating call-to-action assignment) forced students to think creatively about the materials they read and how to apply them in the real world. As these instructors stated:

- $\quad[\mathrm{M}] \mathrm{y}$ students got a lot out of the experience of the VR and saw value in being able to put that on their academic cv/resume as a bonus. (A. Ross, personal communication, March 12, 2021).

- This virtual residency, "Learning for a Sustainable Future," presents such an exciting opportunity for us. Rarely do people from such diverse backgrounds, places, and perspectives come together to address a problem that, presumably, they all agree needs urgent attention ( $\mathrm{J}$. Angiello, personal communication, Nov. 3, 2020).

Creating a sense of community in online instruction is an important part of the IE-VR experience. When students feel that their voices are heard, learning increases drastically (Rogers, 2020c).

\section{Using the Global Learning Qualifications Framework (GLQF)}

An innovative feature of the Fall 2020 "Learning for a Sustainable Future" IE-VR was the intentional adoption of the Global Learning Qualifications Framework (GLQF), a rubric for evaluating college-level learning (State University of New York - Empire State College, 2015). The GLQF is the culmination of over 90 countries and various organizations' perspectives of what is university-level learning (e.g., AAC\&U Value Rubrics, Lumina Degree Qualifications Profile). The framework, which is organized into overarching constructs (i.e., Integration, Engagement, and Knowledge), is used to measure student acquisition of knowledge across learning domains (Applied Knowledge, Integrated Knowledge, Specialized Knowledge, Learning Engagement, Communication, Sociocultural and Civic Engagement, Ethical Responsibility, and Information Literacy) (See Figure 1). The framework is structured to assess overlaps in learning from a holistic approach. The GLQF is content-neutral, providing overall learning outcomes that can be customized for specific applications (Travers \& McQuigge, 2013). The GLQF is presented from both the educator/evaluator and the student perspectives. 


\section{FIGURE 1 \\ GLOBAL LEARNING QUALIFICATIONS FRAMEWORK}

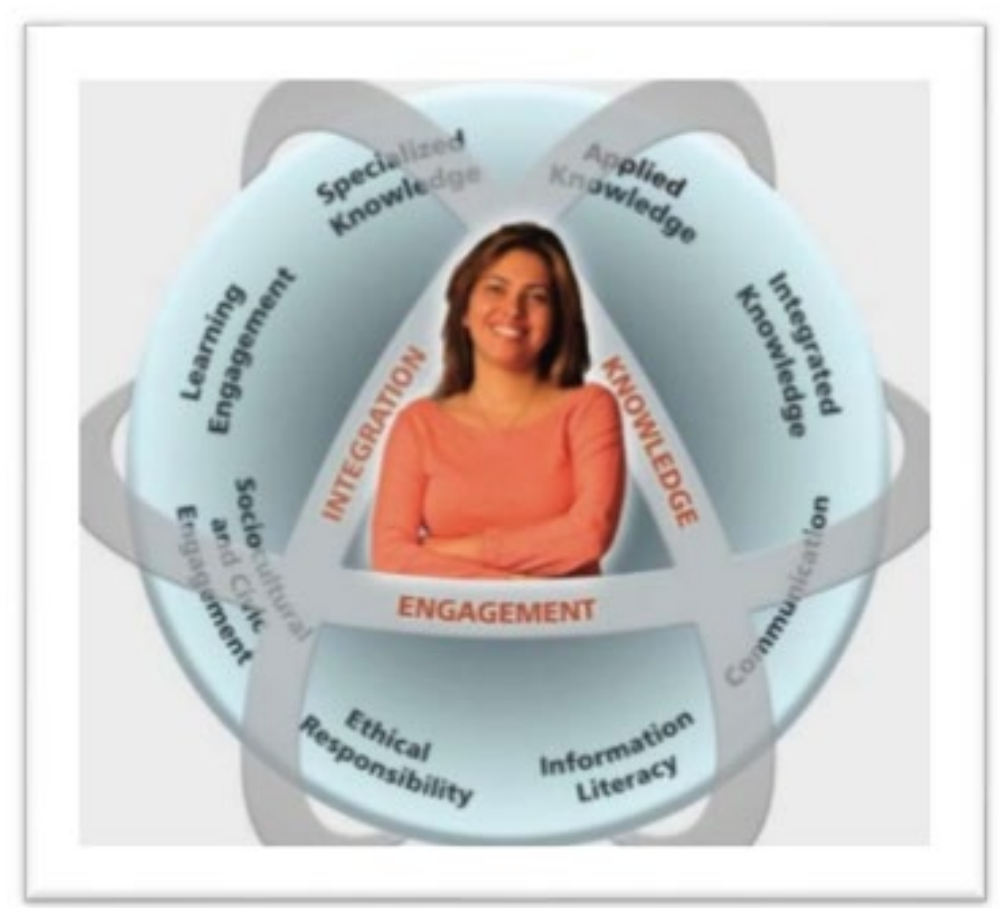

Image adapted from https://www.slideshare.net/NRCPL/global-learning-qualifications-framework

In the development of the IE-VR, we used curricular mapping to highlight the connection between our learning activities and selected GLQF outcomes (See Table 3). The goal was to measure the effectiveness of our assignments and outcomes and determine if students achieved our intended goals for the IE-VR.

\section{TABLE 3 \\ LEARNING OUTCOMES}

Upon completion of this 3-week virtual residency module, the learner will be able to:*GLQF LD:

\begin{tabular}{|c|c|c|c|c|}
\hline CLO \#1 & & $\begin{array}{c}\text { Week } \\
1\end{array}$ & Week & $\begin{array}{l}\text { Week } \\
3\end{array}$ \\
\hline 1.1 & $\begin{array}{l}\text { Learning Outcome: Evaluate their perspective while charting } \\
\text { steps toward growth as global citizens for sustainability. (GLQF } \\
\text { LDs*: Communication \& Sociocultural and Civic Engagement- } \\
\text { Lower Level) }\end{array}$ & & $\mathrm{X}$ & $\mathrm{X}$ \\
\hline 1.2 & $\begin{array}{l}\text { Communicate knowledge in a content area accurately, coherently, } \\
\text { and clearly, informed by key concepts, techniques, and } \\
\text { developments in the field. }\end{array}$ & $\mathrm{X}$ & $\mathrm{X}$ & $\mathrm{X}$ \\
\hline 1.3 & $\begin{array}{l}\text { Demonstrate insight into one's own identity and biases and the } \\
\text { influence they have on understanding and interacting with others. }\end{array}$ & & $\mathrm{X}$ & $\mathrm{X}$ \\
\hline 1.4 & $\begin{array}{l}\text { Demonstrate acceptance for and willingness to learn from diverse } \\
\text { perspectives and backgrounds with different social/community } \\
\text { groupings and audiences. }\end{array}$ & $\mathrm{X}$ & $\mathrm{X}$ & $\mathrm{X}$ \\
\hline CLO \#2 & $\begin{array}{l}\text { Learning Outcome: Apply the UN's } 17 \text { Sustainable Development } \\
\text { Goals to specific case studies in order to address issues that }\end{array}$ & & & \\
\hline
\end{tabular}




\begin{tabular}{|c|c|c|c|c|}
\hline & $\begin{array}{l}\text { threaten sustainable models or systems. (GLQF LDs: Specialized } \\
\text { knowledge \& Applied knowledge-Lower Level) }\end{array}$ & & & \\
\hline 2.1 & Build on prior knowledge, skills and competencies. & $\mathrm{X}$ & $\mathrm{X}$ & $\mathrm{X}$ \\
\hline 2.2 & $\begin{array}{l}\text { Analyze information and construct a coherent argument to } \\
\text { address concerns and/or solve problems. }\end{array}$ & & & $\mathrm{X}$ \\
\hline 2.3 & $\begin{array}{l}\text { Apply technical and professional knowledge in the analysis and } \\
\text { resolution of practical issues. }\end{array}$ & & & $\mathrm{X}$ \\
\hline 2.4 & $\begin{array}{l}\text { Analyze and interpret theoretical, technical and research } \\
\text { information and apply it to specific situations. }\end{array}$ & & & $\mathrm{X}$ \\
\hline CLO \#3 & $\begin{array}{l}\text { Learning Outcome: Engage in intercultural, reflective } \\
\text { investigation(s) on sustainability to develop cultural engagement } \\
\text { and cross-cultural competencies. (GLQF LDs: Communication \& } \\
\text { Sociocultural and Civic Engagement-Higher Level) }\end{array}$ & & & \\
\hline 3.1 & $\begin{array}{l}\text { Accurately and reliably communicate to develop authority and } \\
\text { credibility. }\end{array}$ & $\mathrm{X}$ & $\mathrm{X}$ & $\bar{X}$ \\
\hline 3.2 & $\begin{array}{l}\text { Communicate original perspectives and own voice on information } \\
\text { and concerns within an area. }\end{array}$ & $\mathrm{X}$ & $\mathrm{X}$ & $\bar{X}$ \\
\hline 3.3 & $\begin{array}{l}\text { Gains new perspectives on one's identity and biases based on } \\
\text { experiences and interactions with others and the community. }\end{array}$ & $\mathrm{X}$ & $\mathrm{X}$ & $\mathrm{X}$ \\
\hline 3.4 & $\begin{array}{l}\text { Analyze political/non-political, public/private, and local/global } \\
\text { policies, practices, and decisions to draw conclusions or take } \\
\text { action. }\end{array}$ & & $\mathrm{X}$ & $\mathrm{X}$ \\
\hline CLO \#4 & $\begin{array}{l}\text { Learning Outcome: Develop a positionality towards civic } \\
\text { engagement and affirm sustainability in a holistic manner with } \\
\text { values of diversity, equity, and inclusion. (GLQF LDs: Ethical } \\
\text { Responsibility, Sociocultural and Civic Engagement, \& } \\
\text { Integrated Knowledge-Higher Level) }\end{array}$ & & & \\
\hline 4.1 & $\begin{array}{l}\text { Recognize different perspectives and analyze situations to provide } \\
\text { best solutions under particular circumstances according to the } \\
\text { standards of practice and ethics of the field. }\end{array}$ & $\mathrm{X}$ & $X$ & \\
\hline 4.2 & $\begin{array}{l}\text { Assess the impact of different activities on the environment, } \\
\text { society and the field and develop a sense of social responsibility } \\
\text { while making judgements and decisions on these activities. }\end{array}$ & $\mathrm{X}$ & $\mathrm{X}$ & $\mathrm{X}$ \\
\hline 4.3 & $\begin{array}{l}\text { Predict and determine the impact of one's own behaviors and } \\
\text { actions and their implications in different social/community } \\
\text { groupings and audiences. }\end{array}$ & & & $\mathrm{X}$ \\
\hline 4.4 & $\begin{array}{l}\text { Analyze political/non-political, public/private, and local/global } \\
\text { policies, practices and decisions to draw conclusions or take } \\
\text { action. }\end{array}$ & & & $\mathrm{X}$ \\
\hline 4.5 & $\begin{array}{l}\text { Interpret relevant information and create relational connections to } \\
\text { solve problems across various contexts. }\end{array}$ & & & $\bar{X}$ \\
\hline 4.6 & $\begin{array}{l}\text { Synthesize, integrate and apply knowledge in new and creative } \\
\text { ways and/or to form new perspectives and/or solve problems. }\end{array}$ & & & $\mathrm{X}$ \\
\hline
\end{tabular}

GLQF LD: Global Learning Qualifications Framework Learning Domains: https://www.esc.edu/global-learningqualifications-framework/learning-domains/_CLO = Common Learning Outcomes.

\section{Transformative Learning \& Critical Pedagogy}

Efforts to connect education for sustainability (EfS) with transformative learning theory (TLT) are not new. Michel et al. (2020) explored the connection as it has developed over a couple of decades and concluded that personal and social transformations are the desired and achieved outcomes when the goals 
of EfS meet with the process of TLT. Cottafava, Covaglià, and Corrazza (2019) constructed a framework for the education of sustainable development goals with procedural structure from TLT and guidance from UNESCO. Howlett, Ferreira, and Blomfield (2016) emphasized how a transformative education for sustainability must be rich in interdisciplinary study. The IE-VR has in its foundation a commitment to focus on the SDGs from an interdisciplinary approach. As a goal of our IE-VR, we strived to create a space for transformative learning that resulted in some form of civic action (Mezirow, 1978). When developing a curriculum with a transformative focus, we must develop meaningful participation that encourages a diversity of voice. Instruction should encourage critical analysis and offer multiple approaches and solutions to the topic. To emphasize the collaborative spirit of this inclusive learning environment, Rogers (2020d) added this discussion post:

Thinking across disciplines: This is something that is really beneficial about this VR experience. Each of you is bringing in something unique, a different disciplinary focus, different course experiences, different life experiences, and different cultures. These are an asset. When we think across cultures and disciplines, we can add to your learning experience.

Recognizing these perspectives is one way to create a dialogue across belief systems. Including these perspectives encouraged critical thinking through the process of deliberative conversations, which are "meant to intentionally bring together individuals who represent diverse perspectives around a topic; sometimes difficult or controversial, to advocate for tangible, joint solutions that give a voice to all invested in the conversation" (Rogers, 2020a, paragraph 2). In this current time of global unrest, we have chosen to focus on these difficult dialogues to enhance transformative learning for our participants.

Using the curricular map to achieve the overarching goals of the IE-VR, we were able to create a learning environment that challenges and supports students in growing toward global citizenship (See Figure 2). At the core of our assignments were the concepts we felt drove sustainability models and systems (e.g., sustainability advocacy, agency, critical thinking, civic action, social responsibility, ethics, diversity, and scientific literacy).

FIGURE 2

SUSTAINABILITY IE-VR TRANSFORMATIVE LEARNING MODEL

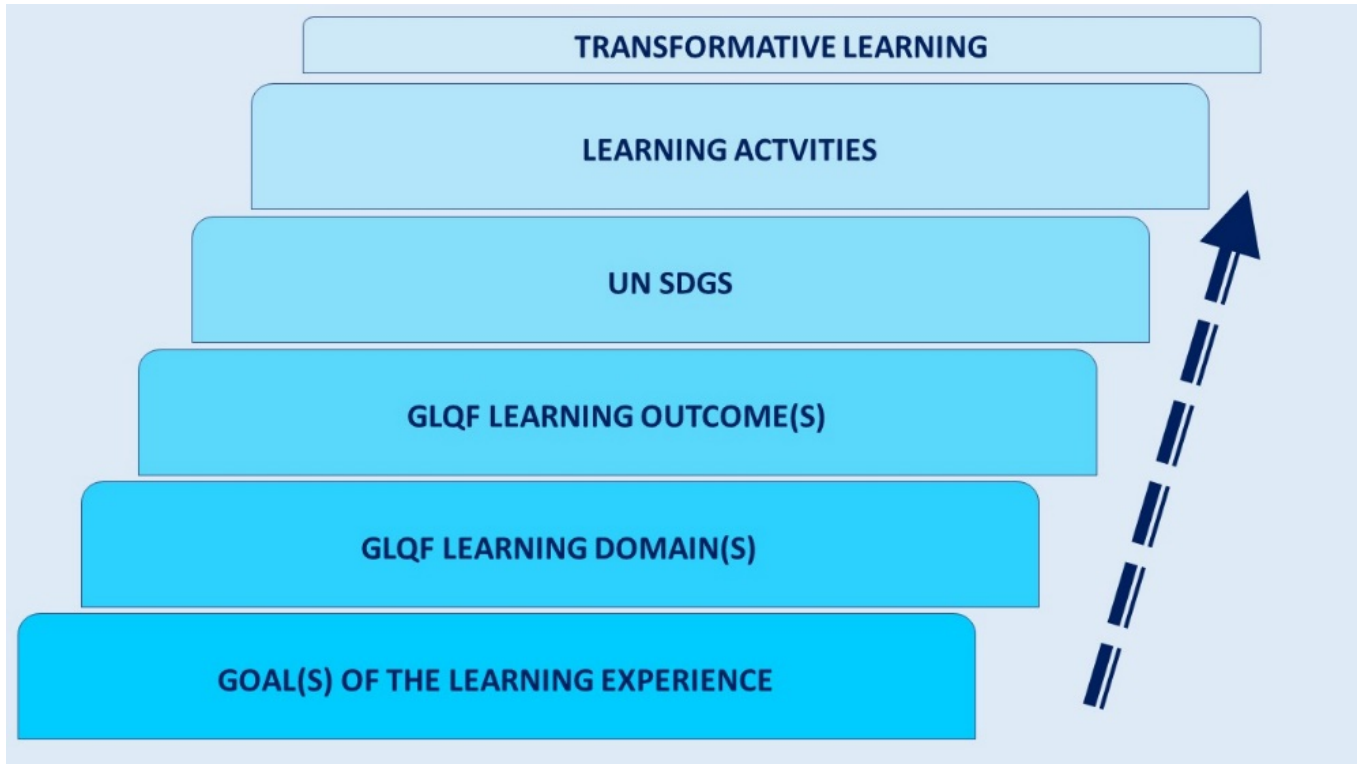


Transformative education has the goal of bringing learners to a more insightful perspective after a period of critical reflection (Mezirow, 1978, 2012; Mezirow \& Associates, 2000). This was our goal with the IE-VR. We wanted participating students and instructors to leave the IE-VR with a sense of heightened awareness and a will to act courageously as local, national, and global citizens in a world needing urgent and systemic change for sustainability. The three weeks of the IE-VR should be only a beginning as learners continue to engage in problem posing, critical investigation, reflection, and direct action. At stake is nothing less than the future of life on Earth for humans and countless other species.

\section{FALL 2020 IE-VR CASE STUDY: LEARNING FOR A SUSTAINABLE FUTURE METHODOLOGY AND DATA COLLECTION}

During the IE-VR experience, students participated in four discussion forums which were designed to provide a global, transdisciplinary view of sustainability and sustainable development. At the end of the experience, students also completed an optional survey, which directly connected the learning outcomes to their perceptions of learning effectiveness. In this study, we used the IE-VR GLQF rubric (Travers \& McQuigge, 2013), SurveyMonkey (2021), content analysis (CA) (Mehl, 2006), and word clouds (Davies, n.d.) to provide multiple representations of the discussion forum data and compare our findings to our IEVR goals and learning outcomes.

It is important to note that participation in each discussion forum and the overall IE-VR experience varied by course, given that faculty either made the assignments required or optional. On average, between 40-50 students out of the 82 enrolled engaged in each discussion forum. At the end of the 3-week experience, all students were given a link to an online optional survey, which the authors created using SurveyMonkey (2021). In this survey, students were asked to rate the effectiveness of each learning outcome on a scale of 1-5, 1 being the lowest and 5 being the highest. Though the response rate was low (18:82 respondents), the survey produced a median average of 4.5 out of 5 ratings for each learning outcome; meaning that the small student sample did, in fact, believe the aforementioned learning outcomes were met during this residency. Given the low response rates for the optional survey, we generated a series of word clouds (Davies, n.d.) for each discussion forum to visualize the word frequencies and identify the words/word clusters related to the GLQF to use in our content analysis.

\section{Analysis of Student Learning: Learning for a Sustainable Future IE/VR Discussion Forums}

To complete our content analysis, we determined the presence of certain words, themes, or concepts related to sustainability within the text of the IE-VR discussion forums (Elo S, Kaarianinen M, Kanste O, Polkki R, Utriainen K, \& Kyngas H., 2014). We selected words that were emphasized in the GLQF outcomes we adapted to assess student learning and words that figured prominently in the word clouds we created to visually represent each discussion forum (See Figures 3-6). For words that appeared to have similar meanings for students, based on the context in which the words appeared in the discussions, we created word clusters to represent a single theme or attribute. For example, we grouped sustainability, sustainable, and sustain in one group and global, globe, earth, planet, and world in another (See Table 4). Results from our content analysis of the discussion forums (See Table 4) and our assessment of the forums using the GLQF rubric (See Discussion Forum Analysis sections below) affirm students' self-assessments recorded in the survey. The results demonstrate that sustainability was the primary focus of student discussions across the IE-VR (See Table 4). Through a comparison of the content analyses for each

discussion forum, we learned that students envision sustainability at a global scale within the contexts of human experiences and change. Climate, food security, and water quality were specific environmental concerns students considered as they assessed sustainable development and proposed solutions to meet the UN SDGs (See Table 4 and Discussion Forum Analysis sections below). 
TABLE 4

SUSTAINABILITY \& SUSTAINABLE DEVELOPMENT DISCUSSION FORUM WORD FREQUENCIES

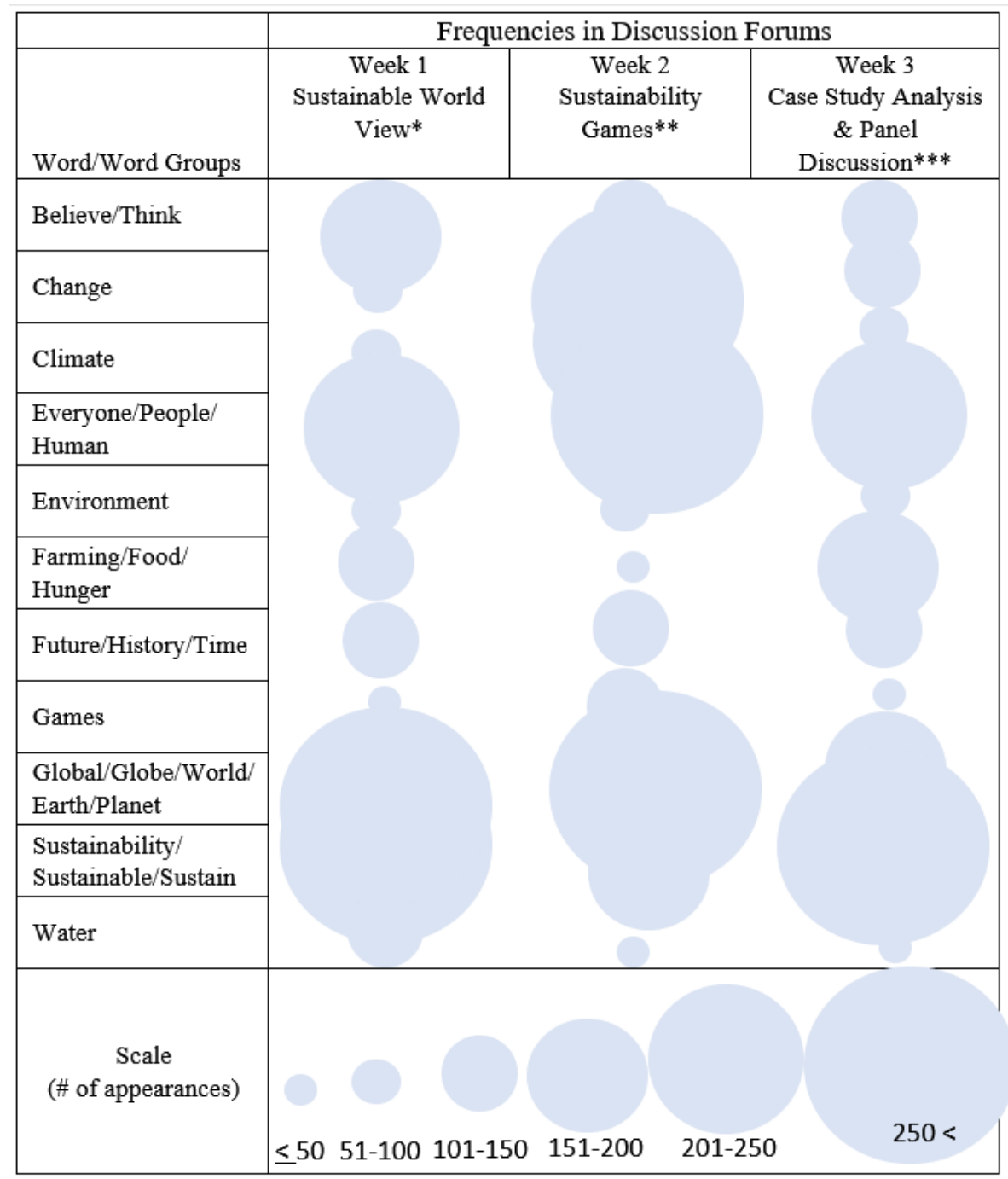

*Week $1=53$ discussion threads, 30,574 words. **Week $2=48$ discuss threads, 31,000 words. $k * *$ Week $3=2$ discussion forums, 68 discussion threads, 34,948

\section{Analysis of Discussion Forum 1: Developing a Shared Understanding of Sustainability and Sustainable Development}

During the first week of the IE-VR, students were invited to participate in their first discussion forum where they began their discussion threads by responding to the following prompts:

How would you define "sustainability"? How would you describe your "sustainability world view"? Please give an example of any experience you have had that informs your current understanding of sustainability. If you have not given this topic much thought, you can be honest about that; however, write what you can. What do you want to learn? What question(s) do you have coming into this? (Rogers, Abendroth, \& Jones, 2020)

After reflecting on their "sustainable worldview," students completed a series of readings, watched videos, and researched the UN SDGs. Once they had completed their initial research on sustainability, they returned 
to the discussion forum to rank their top 3 UN SDGs and respond to the post of at least 2 other participants in the residency. In their responses, students were asked to consider the following:

How do their definitions of sustainability compare to yours? What were common themes/ideas? Were there things that you didn't think of initially? How do their rankings compare with yours? Remember that this is an exploratory learning experience--we are exploring the possibilities--not coming up with a "correct definition" or "worldview." In your response, value and respect the ideas and offered perspectives of other participants. (Rogers, Abendroth, \& Jones, 2020)

Finally, students were asked to revisit their initial post and reflect on what they learned from the readings and videos, and consider how, if at all, their view of sustainability has changed.

Important goals for this assignment were for students to reflect on their definition of sustainability and sustainable development and articulate that definition to residency participants, to explore the inherent complexity involved in defining sustainability, and to critically re-examine their definition after researching broad definitions of sustainability and participating in residency discussions. The goal was not to determine "the definition" of sustainable development but to increase their awareness of the ways that different disciplines, professions, and cultures view sustainability to facilitate communication around complex global challenges.

To assess students' learning experiences in this opening forum, we reviewed the discussion threads within the context of the GLQF learning outcomes mapped to this week's learning activities (See Table 3). We observed that students focused their initial discussion posts on articulating what sustainability means to them. For students who were building on prior experiences with sustainability, they drew upon personal experiences to support their definitions of sustainability. Their personal experiences also informed which UN SDGs they found to be of greatest importance-where action and solutions were most needed (See Table 3; CLO \#2). Those who were new to sustainability, highlighted the importance of this residency to them as a learning experience as they became aware of the challenges that the SDGs are attempting to address. Words that appeared often in the initial posts included "think" and "believe" (See Figure 3), and these words were used by students to emphasize their ownership of their perspectives as they navigated the discussion (See Table 3; CLO \#3).

In students' responses to the definitions of others, they shared their evaluations of the ways their definitions and ranking of the SDGs compared with their initial definition. We observed posts of "affirmation," where students expressed excitement that they had found another individual who shared their idea of sustainability and valued the need for solutions and/or calls for action related to the SDGs they had ranked the highest. We also observed posts of "reconsideration," where students communicated that they were re-evaluating their rankings and definition in light of the post of another student whose experiences had led them to rank the SDGs differently (See Table 3; CLOs \#1 \& 4). This re-evaluation often occurred when students in different programs (e.g. School for Undergraduate Studies and International Education) shared their rankings and after students had read selected readings and viewed recordings.

The word clouds that we created to visually assess the content of the discussion highlight topics and themes on which students focused their discussion (See Figure 3). In the content analysis for this discussion forum (53 threads; 30,574words), we observed that the most frequent words were consistent with the primary topics of the opening forum, definition of sustainability and sustainable development and ranking of the UN SDGs, "sustainability," "sustainable," "development," and "SDGs" together $(n=494)$ were the most prominent words in the word cloud (See Table 4). The next group of words to figure prominently in the discussion were words of scale: "world," "Earth," and "global" $(n=238)$. Other words of prominence in the word clouds relate to specific challenges captured in the SDGs for which solutions are needed including "water," "food," "hunger," "environment," "education," "resources," "climate," "clean," "poverty," "gender," and "economic" (presented in descending order of frequency). Words emphasizing action, "need," "work," and "action," also appeared with relatively high frequency. Through their first discussions, students worked through the complexity associated with defining sustainability and prioritizing 
SDGs. They emerged as a dynamic learning community, sharing their analyses and re-evaluating their perspectives.

\section{FIGURE 3 \\ WORD CLOUD CREATED FROM THE TEXT FROM DISCUSSION FORUM 1}

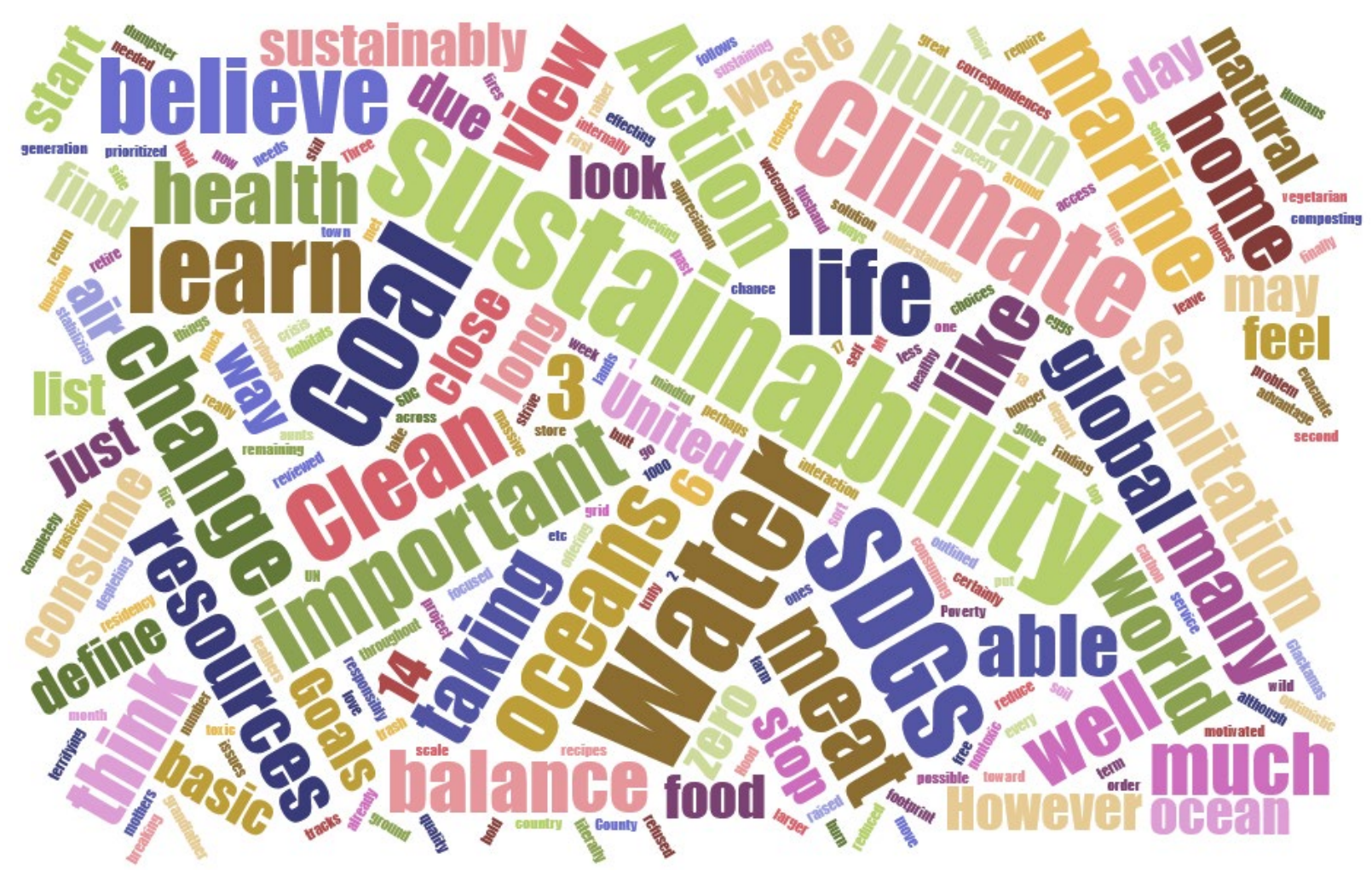

Analysis of Discussion Forum 2: Sustainable Learning - Virtual Games

This module focused on applied learning, specifically the ways that students could learn about sustainability through games and national and international case studies. Interactive games provide a way to work through challenges and issues. They also provide a safe environment to develop models, explore interactions and reactions, and test solutions to complex, multilayered challenges. Students were prompted with the following statement:

In the list below, we provide you with a selection of games related to one or more of the UN's SDGs. Select at least one and participate... Consider ways the pieces affirm or challenge your sustainable world view. Think about possible ways the ideas, concepts, analyses, methodologies, philosophies presented in the pieces might contribute to the development and implementation of sustainable solutions to unsustainable situations. (Rogers, Abendroth, \& Jones, 2020)

The Week 2 readings and recordings included a variety of cultural, environmental, and social perspectives related to sustainability and sustainable development. During this week, we also asked participants to prepare for their discussion of a presentation led by an international panel of scholars and professionals who focus their work on sustainability and sustainable development fields. We provided participants with a variety of sustainability readings and recordings across scientific, social, and cultural disciplines and asked that they select a number to review. Textual analysis of all discussion comments $(n=31,000$ words 
written by 42 participants) illustrated that the words most frequently used were "change," (n=285), "climate," (n=250), "people," (n=167) and "games" $(n=122)$.

\section{FIGURE 4 WORD CLOUD CREATED FROM THE TEXT FROM DISCUSSION FORUM 2}

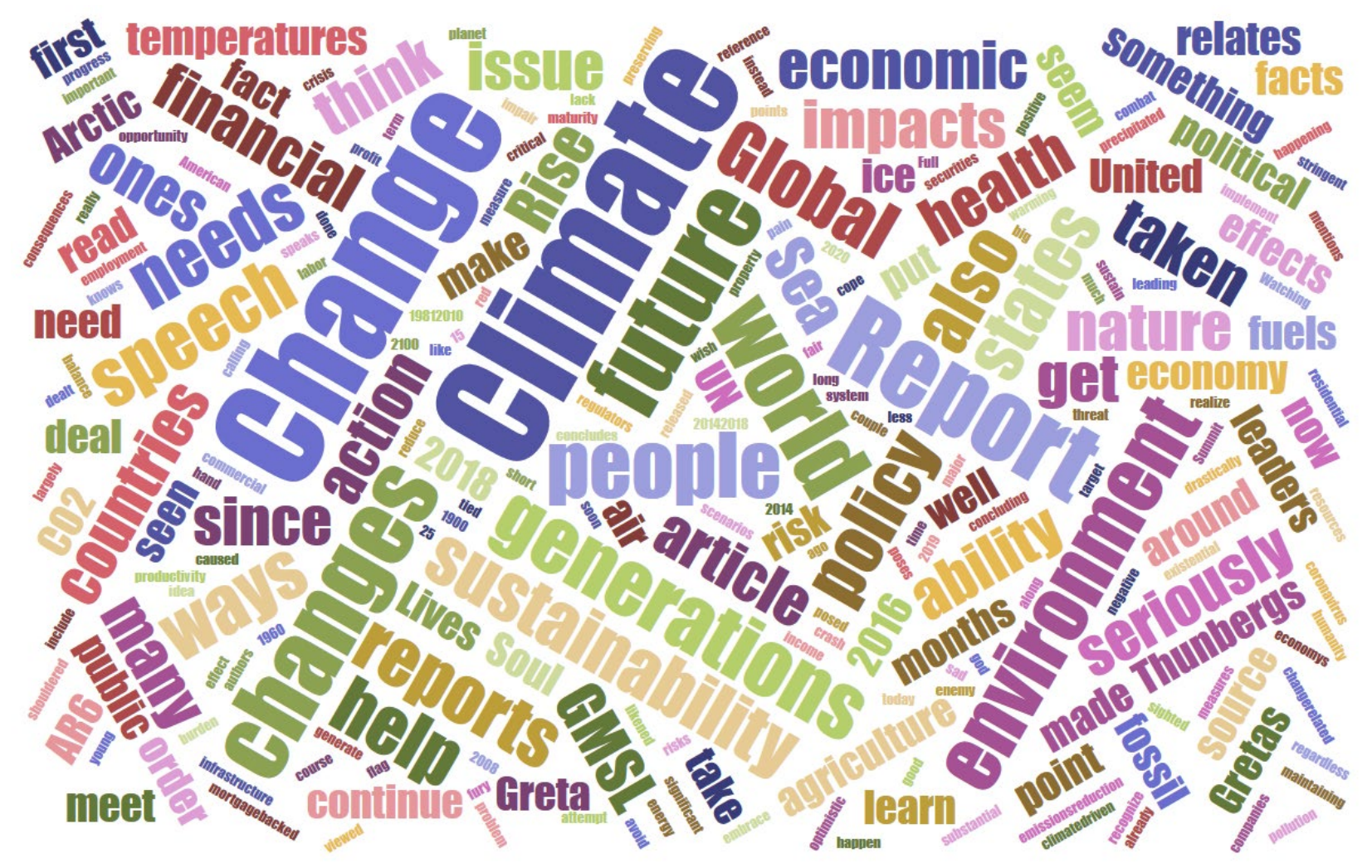

The frequency of these worlds is no surprise. Students were asked to evaluate case studies and to play games addressing climate change such as Mr. Genius (Legends of Learning, n.d.-a) and Escape Global Climate Change (Legends of Learning, n.d.-b). The most common referenced article in this section was Greta Thunberg's speech to the UN (Public Broadcast System News Hour, 2019) followed closely by the scholar Robin Kimmerer's (Potawatomi Nation and professor of Environmental Science and Forestry) address to Bioneers (2014) on environmental change from a native worldview. What was interesting about this section of discussion was that the games themselves were not referenced by name in as high of frequency as suspected; instead, learning from the games was more commonly discussed (e.g., that concrete was a cause of pollution rather than the game Escape Global Climate Change and that the definition of climate was clarified by the Mr. Genius game). This may be the result of students' thinking that learning through games is less "academic" than learning through lectures and written text, so they choose to reference those materials more frequently than the games themselves. As with the prior discussion, students continued to express excitement when they had found other individuals who shared their idea of sustainability and reflective learning. This re-evaluation often occurred when students in different programs (e.g. School for Undergraduate Studies and International Education) shared their thoughts about the case studies and after students had read selected readings and viewed recordings and shared their additional thoughts. 


\section{Analysis of Discussion Forum 3: Developing a Shared Understanding of Sustainability and Sustainable Development}

During the $3^{\text {rd }}$ week of the IE-VR, students participated in 2 discussion forums: "Thoughts and Reflections," related to a panel presentation, and "Developing a Shared Understanding of Sustainability and Sustainable Development," related to case study analyses. Our content analysis includes word frequencies for the week as a whole, allowing us to observe content trends throughout the three-week experience (See Table 4) and individual discussion forum analysis, allowing us to observe specific content trends within each discussion. The final assignment of the IE-VR gave students the opportunities to reflect on one of three provided case studies and one case study of their choice outside the IE-VR. The three provided cases included one on Puerto Rico after Hurricane Maria (Australian Broadcasting Corporation, 2019), one on farming innovations on rooftops in cities (Deutsche Welle, 2014), and one on food sovereignty through regenerative farming (Sherrange, 2020). Two of these three addressed farming and food directly. The discussion forum for the final week gave students three points to address: 1) summarize the two case studies chosen, 2) identify up to three UN SDGs associated with each case study, and 3) identify ways in which the case studies inspired thinking about how to become a better global citizen for sustainability.

The discussion forum for week 3 generated a total of 23,389 words in the texts of posts and replies among 35 students. The five most common words or related word groups that emerged are as follows with their frequency: farming/food $(\mathrm{n}=148)$, sustainable/sustainability $(\mathrm{n}=138)$, everyone/people/human $(n=119)$, future/history/time $(n=81)$, global/globe/world $(n=81)$. Among other significant words/phrases was "SDGs" with 63 occurrences.

\section{FIGURE 5 \\ WORD CLOUDS CREATED FROM THE TEXT FROM DISCUSSION FORUM 3}

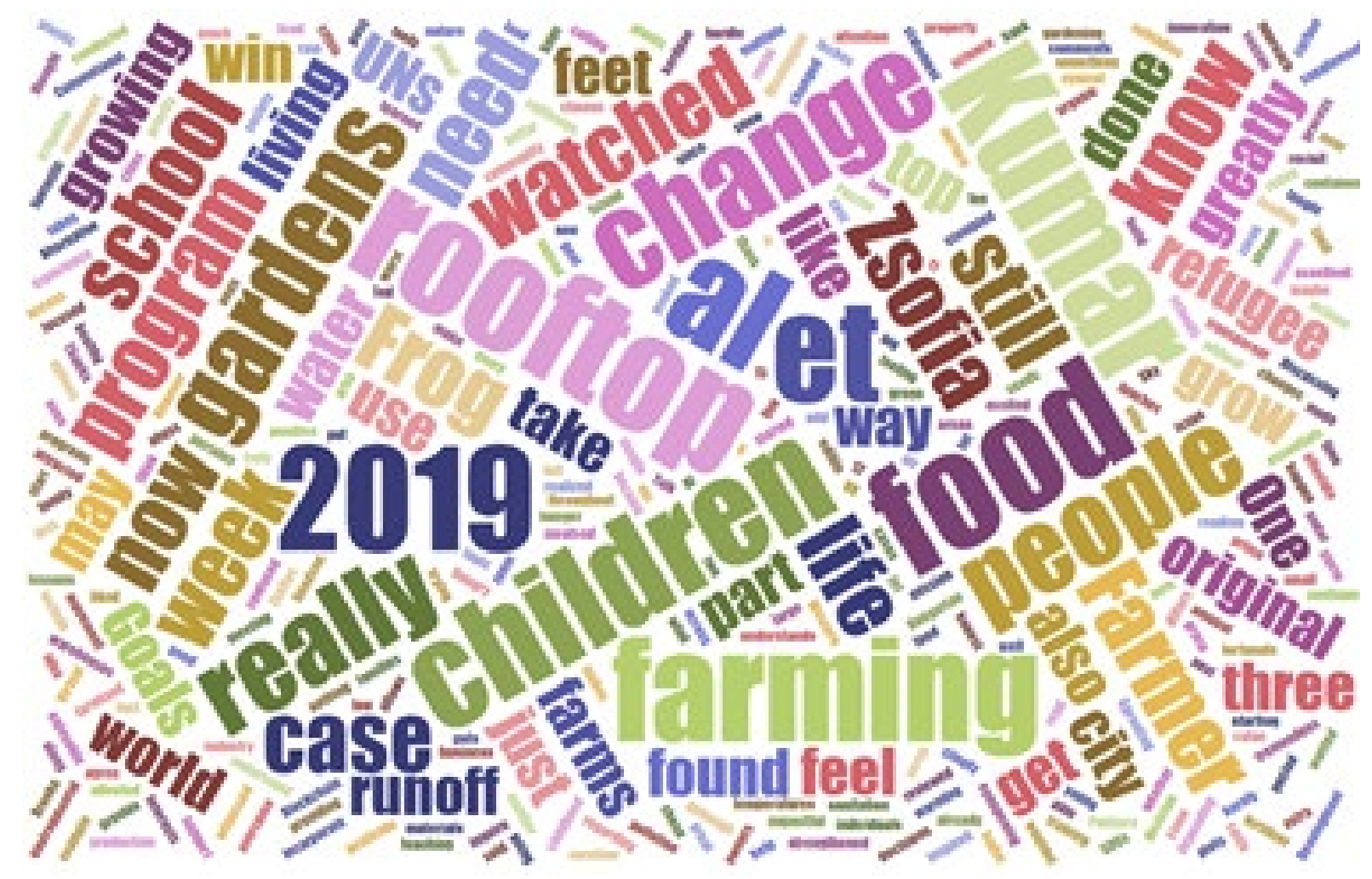

It is not surprising to find "farming/food" at the top of the list since two of the three provided case studies address this directly. Also, the high frequency of "sustainable/sustainability" is expected as this is 
the entire IE-VR's center of focus. The frequent inclusion of "everyone/people/human" shows the common perception of social responsibility for achieving sustainability. The high occurrences of "future/history/time" point to awareness of the need to study history toward working for a sustainable future. The high result for "global/globe/world" demonstrates that students identified global connections from their chosen case studies.

These findings provide evidence that the work of the third week aligned well with all four content learning objectives (See Table 3; CLOs \#1- \#4). The uses of "global/globe/world" and "future/history/time" point to an awareness of global citizenship (See Table 3; CLO \#1). The frequent naming of SDGs connects directly with student's application of the SDGs as the developed solutions in their case study analyses (See Table 3; CLO \#2). The highly frequent use of "farming/food" aligns with the focus on cultural engagement (See Table 3; CLO \#3). A central concept within a culture is how people use the land to meet their needs, and two case studies offered a diverse perspective of this concept. Finally, the use of "everyone/people/human" reflects an awareness of social responsibility to promote equity, diversity, and inclusion (See Table 3; CLO \#4). These sets of connections overlap and blend to some extent, but these given above are examples that stand out.

\section{Analysis of Discussion Forum: Thoughts and Reflections}

At the beginning of the third and final week of the residency, students attended a discussion of sustainability and sustainable development presented by an international panel of scholars and professionals working in sustainability fields. After participating in or listening to the panel session, students were asked to participate in a discussion titled "Thoughts and Reflections" according to the following prompt:

Please review your notes or watch the recording of the panel. Students who have been required to attend the session and were unable to attend should use this forum to discuss their ideas about the keynote here. Students who did attend can also contribute. (Rogers, Abendroth, \& Jones, 2020)

The goals for the discussion forum related to the panel discussion were similar to those outlined for Discussion Forum 1, with the addition of outcomes related to the application of their learning during the first two weeks of the residency and to transformative learning (See Table 3; CLOs \#1.1, 1.3, 4.2 \& 4.4). We observed a shift like the discussions presented in this discussion forum in the final week of the residency. The panel presenters not only described local, regional, and global challenges and barriers related to sustainable development, they offered potential solutions at individual and community scale, a scale which students expressed enabled them to envision specific actions they could take towards a more sustainable future. As in the previous discussion forums, "sustainability" and "sustainable" $(\mathrm{n}=124)$ were featured prominently with "people/human/everyone" $(\mathrm{n}=94)$, and "planet/world/Earth" (n= 75) (30 discussion threads; 11,559 words) (See Table $4 \&$ Figure 6). Additionally, we observed a slight shift in the words emphasized. Other words/word clusters focused on legacy and community action: "future/history/ time," "education," "need," and "work/action/change" (See Figure 6). In response to the panel presenters, students focused their discussions this week on the action, education, and communities (See Table 3; CLOs \#1 \& 2). Their discussions emphasized a call for action that everyone needs to answer because of the work required to ensure a sustainable future which includes education related to climate change, food security, natural resources, and poverty. In the content analysis of this discussion forum, we observed that "think" and "believe" were used by students to articulate specific actions that are needed to achieve SDGs (actions they needed to take or actions that were needed by members of the larger community). In this discussion forum, we observed transformative learning. Students were beginning to apply what they were learning from course materials, panel discussions, and each other to develop sustainable solutions to the challenges they had identified during the first week of the residency. 
FIGURE 6

\section{WORD CLOUDS CREATED FROM THE TEXT FROM DISCUSSION FORUM: THOUGHTS} AND REFLECTIONS ON THE PANEL DISCUSSION

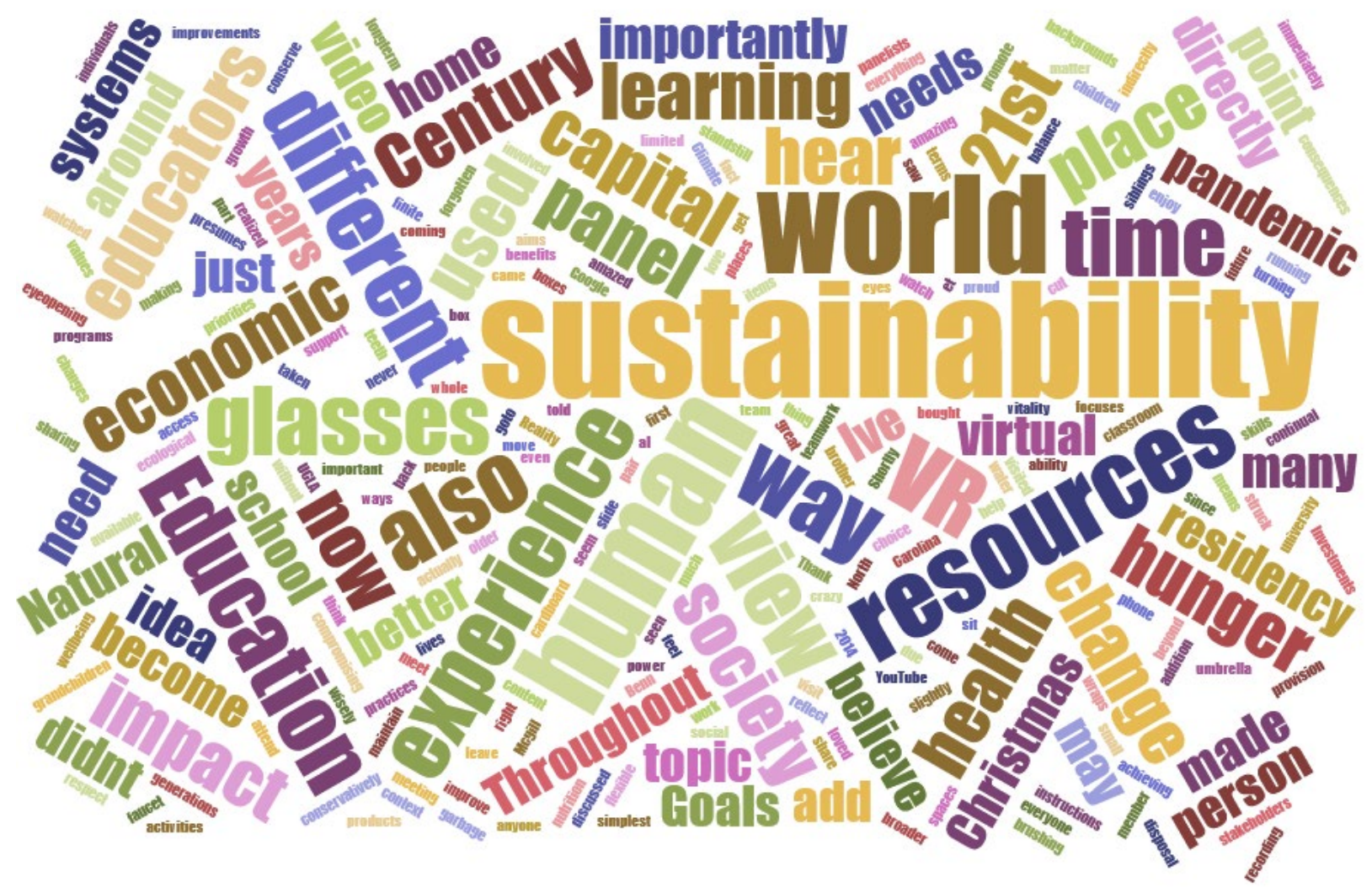

\section{CONCLUSION}

We offer this IE-VR case study as a model for educators seeking to develop inclusive learning platforms that engage students in sustainable development and offer learners a transdisciplinary way to collaborate across cultures (Abendroth, Rogers, \& Jones, 2020). We observe that the "Learning for a Sustainable Future" residency exchange offers participants the resources and critical frameworks to prepare them for contributing to the solution-making efforts of today's socio-cultural and socio-environmental issues. The inclusion of both the GLQF and SDGs appears to have enhanced the retention of knowledge and facilitated the assessment of student learning. As we have seen in the COVID-19 era, the world is changing, and we can no longer rely on traditional learning methods to engage students online. This model can also inform the rapid transformation of traditional classrooms into effective virtual learning environments during times of crisis, serving as a sustainable solution for higher education. Our future depends on how well we teach future generations and transform their sustainability practices.

\section{ACKNOWLEDGEMENTS}

This research was supported by a 2020-2021 SUNY Empire State College - Institute on Mentoring, Teaching, and Learning (IMTL) research project. We thank our colleagues, Drs. Alan Mandell and Shantih Clemens, who provided IMTL supports that greatly benefited this research, although neither were involved in the interpretations or conclusions of this paper. 


\section{REFERENCES}

Abendroth, M., Rogers, R.C., \& Jones, L.S. (2020, September 21-22). Using technological innovations and interdisciplinary approaches to teaching sustainable development: A virtual residency case study [Conference presentation]. IC-SD 2020 Convention, online. Retrieved from https://icsd.org/wp-content/uploads/2020/11/Rhianna-Rogers.pdf

Australian Broadcasting Corporation. (Producer). (2018). Blockchain island [film].

Bioneers. (2014). Robin Kimmerer - Mishkos Kenomagwen: The teachings of grass [film]. Retrieved from https://www.youtube.com/watch?v=cumEQcRMY3c

Cottafava, D., Covaglià, G., \& Corrazza, L. (2019). Education of sustainable development goals through students' active engagement. Sustainable Accounting, Policy, and Management Journal, 10(3). 521-544. https://doi.org/10.1108/SAMPJ-05-2018-0152

Costello, A., Abbas, M., Allen, A., Ball, S., Bell, S., Bellamy, R., . . Patterson, C. (2009). Managing the health effects of climate change. The Lancet, 373(9676), 1693-1733.

Davies, J. (n.d.). Word cloud generator. Retrieved from https://www.jasondavies.com/wordcloud/

Deutsche Welle. (Producer). (2014). The sky's the limit [film].

Haluza-DeLay, R. (2014). Religion and climate change: Varieties in viewpoints and practices. Wiley Interdisciplinary Reviews: Climate Change, 5(2), 261-279.

Howlett, C., Ferreira, J.A., \& Blomfield, J. (2016). Teaching sustainable development in higher education: Building critical, reflective thinkers through an interdisciplinary approach. International Journal of Sustainability in Higher Education, 17(3), 305-321.

Legends of Learning. (n.d.-a). Mr. Genius [online video game]. Retrieved from https://games.legendsoflearning.com/game/mr-genius-global-climatechange/1369? partner=legends-public\&media= game

Legends of Learning. (n.d.-b). Escape global climate change [online video game]. Retrieved from https://games.legendsoflearning.com/game/escape-global-climate-change/361?partner=legendspublic\&media $=$ game

Mehl, M.R. (2006). Quantitative text analysis. In M. Eid \& E. Diener (Eds.), Handbook of multimethod measurement in psychology (pp. 141-156). American Psychological Association. https://doi.org/10.1037/11383-011

Mercer, J., Pisutova, K., \& Rogers, R. (2018). From mystery to mastery: Creating \& enhancing the ultimate virtual classroom experience. In 2018 COIL Conference Proceedings (pp. 112-124).

Mezirow, J. (1978). Perspective transformation. Adult Education, 28(2), 100-110.

Mezirow, J. (2012). Learning to think like an adult: Core concepts of transformative theory. In E.W. Taylor \& P. Cranton (Eds.), The handbook of transformative learning: Theory, research, and practice (pp. 73-95). Hoboken, NJ: John Wiley \& Sons, Inc.

Mezirow, J., \& Associates. (Eds.). (2000). Learning as transformation: Critical perspectives on a theory in progress. San Francisco, CA: Jossey-Bass.

Michel, J.O., Holland, L.M., Brunnquell, C., \& Sterling, S. (2020). The ideal outcome for education for sustainability: Transformative sustainability learning. New Directions for Teaching and Learning, 161, 177-188.

Philip, R.L. (2015). Caught in the headlights: Designing for creative learning and teaching in higher education. [Doctoral dissertation]. Semantic Scholar.

Public Broadcast System - NewsHour Productions. (Producer). (2019). Climate activist Greta Thunberg on the power of a movement. [TV series episode]. Retrieved from https://www.youtube.com/watch?v=KAJsdgTPJpU

Rogers, R. (2020a). The Buffalo Project. Retrieved from https://thebuffaloproject.wixsite.com/tbpinternship

Rogers, R. (Executive Producer). (2020b). Using online learning to bridge cultural divides. [Audio Podcast]. Policy Outsider; Rockefeller Institute of Government. Retrieved from 
https://anchor.fm/policy-outsider/episodes/17--Using-Online-Learning-to-Bridge-CulturalDivides-eaijil/a-a1cvfia

Rogers, R. (2020c, November 20). Sustainability through learning - International Education Virtual Residency panel. [Video]. SUNY Empire State College Sustainability through Learning International Education - Virtual Residency. Retrieved from https://www.youtube.com/watch?v=S6pYWZ97DNk\&feature=youtu.be

Rogers, R. (2020d). Thinking across disciplines: An introductory note from Dr. Rhianna [Online forum post]. Moodle. Retrieved from https://moodle.esc.edu/mod/hsuforum/discuss.php?d=2450092

Rogers, R., Abendroth, M., \& Jones, L. (2020). Sustainability through learning [University course]. Moodle. Retrieved from https://moodle.esc.edu/course/view.php?id=49806

Sherrange, D. (2020). Food sovereignty and the future of regenerative farming. Weave News. Retrieved from https://www.weavenews.org/stories/2020/09/02/2020-9-2-food-sovereignty-and-the-futureof-regenerative-farming

State University of New York - Empire State College. (2015). Global Learning Qualification Framework. Retrieved from https://www.esc.edu/global-learning-qualifications-framework/

SurveyMonkey. (2021). Retrieved from surveymonkey.com

Travers, N.L., \& McQuigge, A. (2013). The Global Learning Qualifications Framework. PLA Inside Out: An International Journal on Theory, Research and Practice in Prior Learning Assessment, 2(1), $1-34$.

United Nations. (2020a). United Nations 17 Sustainable Development Goals: 17 Goals to transform our world. Retrieved from https://www.un.org/development/desa/disabilities/envision2030.html

United Nations. (2020b). About the Sustainable Development Goals. Retrieved from https://www.un.org/sustainabledevelopment/sustainable-development-goals/ 